\title{
La fotografía en el Protectorado español. Los fondos fotográficos del Legado Fernando Valderrama en la Biblioteca Islámica (Biblioteca AECID)
}

\author{
María OLIVERA ZALDUA \\ Universidad Complutense de Madrid. Biblioteconomía y Documentación \\ molivera@ucm.es
}

Recibido: Febrero 2014

Aceptado: Mayo 2014

\begin{abstract}
Resumen: El estudio de la fotografía española durante el Protectorado (1912-1956) es un tema de gran interés para conocer la aportación de los profesionales a la historia y cultura de las posesiones en el norte de África. Las publicaciones al respecto están permitiendo conocer a numerosos autores que permanecían en el anonimato, y cuya obra es fundamental para recuperar y mantener la memoria. El fondo fotográfico del legado de Fernando Valderrama, conservado en la Biblioteca Islámica de la Agencia Española de Cooperación Internacional para el Desarrollo, es una fuente imprescindible para completar los estudios, tanto en lo que se refiere a los contenidos como a los fotógrafos. Es objeto de este trabajo realizar un análisis del mismo, contextualizarlo y ponerlo en valor con el fin de completar las investigaciones.
\end{abstract}

Palabras clave: Biblioteca Islámica; Colecciones fotográficas; Fotografía; Historia de la fotografía española; Protectorado; Fernando Valderrama; Difusión del patrimonio

Photography in the Spanish Protectorate.

Photographic archives in Fernando Valderrama's Legacy from the Islamic Library (AECID Library)

\begin{abstract}
The study of Spanish photography during the Protectorate (1912-1956) is a subject of great interest for someone wishing to find out photographers' contribution to the history and culture of Spanish North African territories. In that regard, current publications are allowing us to unveil many authors who had remained anonymous so far, and whose works are basic to recover and maintains historical memory. The photographic base of Fernando Valderrama's Legacy, kept in the Islamic Library, which belongs to the Spanish Agency for International Cooperation for Development, is an essential source to complete any research, regarding both the contents and the photographers. The purpose of the present work is to analyse the base, to put it into context and to asses it in order to complete the research.
\end{abstract}

Keywords: Islamic Library; Photographic Archives; Photography; Spanish Photography History; Protectorate; Fernando Valderrama; Heritage awareness 


\section{INTRODUCCIÓN}

Las fuentes para el estudio de la fotografía en el Protectorado español en Marruecos se encuentran en la prensa, en las bibliotecas, archivos y colecciones públicas y privadas. Son de especial interés los fondos de la Fototeca del Protectorado integrada en la Biblioteca General de Tetuán, y de la Biblioteca Nacional de España, ambos generados por Tomás García Figueras (Rodríguez Jouliá, 1950; López Enamorado, 1989). A estos conjuntos documentales hay que añadir las imágenes realizadas por aficionados y profesionales cuya vinculación con África es muy diversa: militares, fotoperiodistas, viajeros, retratistas o documentalistas.

Para contextualizar el fondo fotográfico de Fernando Valderrama que aquí se estudia, es importante establecer la diferencia entre fondo y colección. Definimos el primero como el conjunto de documentos, con independencia de su tipo, para difundir el contexto o soporte, producidos orgánicamente y/o reunidos y utilizados por una persona física, familia o entidad en el transcurso de sus actividades y funciones como productor; la colección es el conjunto artificial de documentos acumulados sobre la base de alguna característica común sin tener en cuenta su procedencia (ICA, 2000: 16-17).

Es objeto de este trabajo analizar el fondo fotográfico del legado Fernando Valderrama en la Biblioteca Islámica de la Agencia Española de Cooperación Internacional para el Desarrollo (AECID), compuesto por 10 álbumes de temas y autores diversos. El método empleado ha sido, tras la recopilación y revisión bibliográfica, el inventario, su descripción y la posterior valoración de los contenidos, destacando los principales aspectos de interés en relación a las fotografías.

Por lo que respecta al estado de la cuestión y a las fuentes, han sido numerosos los autores que han publicado sobre la Biblioteca Islámica y sus fondos $\mathrm{y}$ colecciones, entre ellos Nuria Torres Santo Domingo (1995), María Victoria Alberola (2004) y Luisa Mora (2012). Sobre la figura y el legado de Fernando Valderrama han escrito Luisa Mora y Juan Manuel Vizcaíno (2012), y en relación con el fondo fotográfico significamos la descripción general de Gómez Barceló (2012) y la presentación del mismo en el número especial, dedicado a la donación de los Cuadernos de la Biblioteca Islámica (2012). Con relación a la fotografía en las posesiones españolas en el norte de África cabe señalar la interesante aportación global de Gómez Barceló (2007) y sus estudios de los fotógrafos Calatayud y Ros (2010). Referencias específicas se encuentran en biografias de autores de prestigio como Alfonso o Calvache, estudiados por Sánchez Vigil (2000, 2001), o en los libros de los protagonistas, entre ellos Muller (1994) o Zubillaga (1951). 


\section{LA BIBLIOTECA ISLÁMICA FÉLIX MARÍA PAREJA DE LA AECID}

La Agencia Española de Cooperación Internacional para el Desarrollo (AECID) cuenta con dos bibliotecas: Hispánica e Islámica. Tanto por la cantidad como por la calidad de sus fondos ambos centros están considerados entre los más importantes de Europa en sus áreas de especialización. Actualmente reúnen cerca de 800.000 volúmenes entre monografías, revistas especializadas y material audiovisual relacionado con las ciencias sociales y humanidades.

La Biblioteca Hispánica fue creada en 1941 con la finalidad de conservar y fomentar la herencia hispánica en los países de América y Filipinas; seis años después recibió los fondos del Consejo de la Hispanidad, y desde entonces ha aceptado donaciones de autores americanos, diplomáticos e intelectuales, lo que la ha convertido en uno de los centros con mayor información sobre América.

La Biblioteca Islámica se fundó en 1954 con la creación del Instituto HispanoÁrabe de Cultura (IHAC), y su objetivo fue el apoyo documental a los investigadores en el mundo islámico. El encargado de realizar esa tarea fue Félix María Pareja, quien reunió la mejor colección de estudios árabes e islámicos de España. En 1988 el IHAC fue sustituido por el Instituto de Cooperación con el Mundo Árabe y posteriormente denominado Instituto de Cooperación en el Mundo Árabe, Mediterráneo y Países en desarrollo, luego integrado en la AECID. Actualmente la dirige Luisa Mora, cuenta con 1.360 títulos de revistas, algunos de ellos con más de un siglo de existencia, de reconocido prestigio académico y gran diversidad lingüística, y con unos 200 títulos en curso que siguen incorporándose a la colección. Así mismo cuenta con 11.200 registros de analíticas o vaciados, de revistas y libros con autoría conjunta; microfichas y microfilmes; 260 mapas y 937 documentos gráficos (láminas, fotografías y tarjetas postales), gran parte de ellos pertenecientes al legado Valderrama que aquí se estudia, del que también forman parte los 60 volúmenes denominados "Miscelánea", 4.400 documentos del archivo personal de Mariano Arribas y 400 archivos audiovisuales. El fondo antiguo con documentos editados antes de 1901, está formado por 1.336 volúmenes y 18 manuscritos (Mora, et al; 2013).

Como centro de excelencia, entre otros objetivos trata de hacer accesible para la comunidad investigadora un fondo de notable interés sobre una de las temáticas más características de la Biblioteca Islámica, el Protectorado. Se hace con acciones coordinadas y simultáneas en el tiempo que también han dado lugar a nuevas adquisiciones (como las donaciones de material gráfico de Ignacio Alcaraz o de Eloy Martín Corrales, entre otros). 


\section{EL LEGADO VALDERRAMA}

Fernando Valderrama Martínez (Melilla, 1912- Madrid, 2004), discípulo de Emilio García Gómez, fue maestro y catedrático en Tetuán, responsable de la Enseñanza Marroquí de la Delegación de Educación y Cultura Española del Protectorado (Figura 1). A partir de 1934 publicó sus primeras obras sobre lengua marroquí: Formación profesional del marroquí (1934) y Estado actual de la enseñanza marroquí (1938), a finales de los años cuarenta y comienzos de los cincuenta difundió manuales didácticos sobre lengua española y marroquí, y en 1951 se doctoró en Filosofía y Letras por la Universidad de Madrid con una investigación sobre el Cancionero de Al-Haik. Investigó además sobre otros aspectos de la cultura del Rif: historia, epigrafia, música, monumentos, etc. En 1956 publicó Historia de la acción cultural de España en Marruecos (1912-1956), en la que se reprodujeron parte de las fotografias de los álbumes que aquí se analizan.

Figura 1. Retrato de Fernando Valderrama Martínez.

Colección familia Valderrama

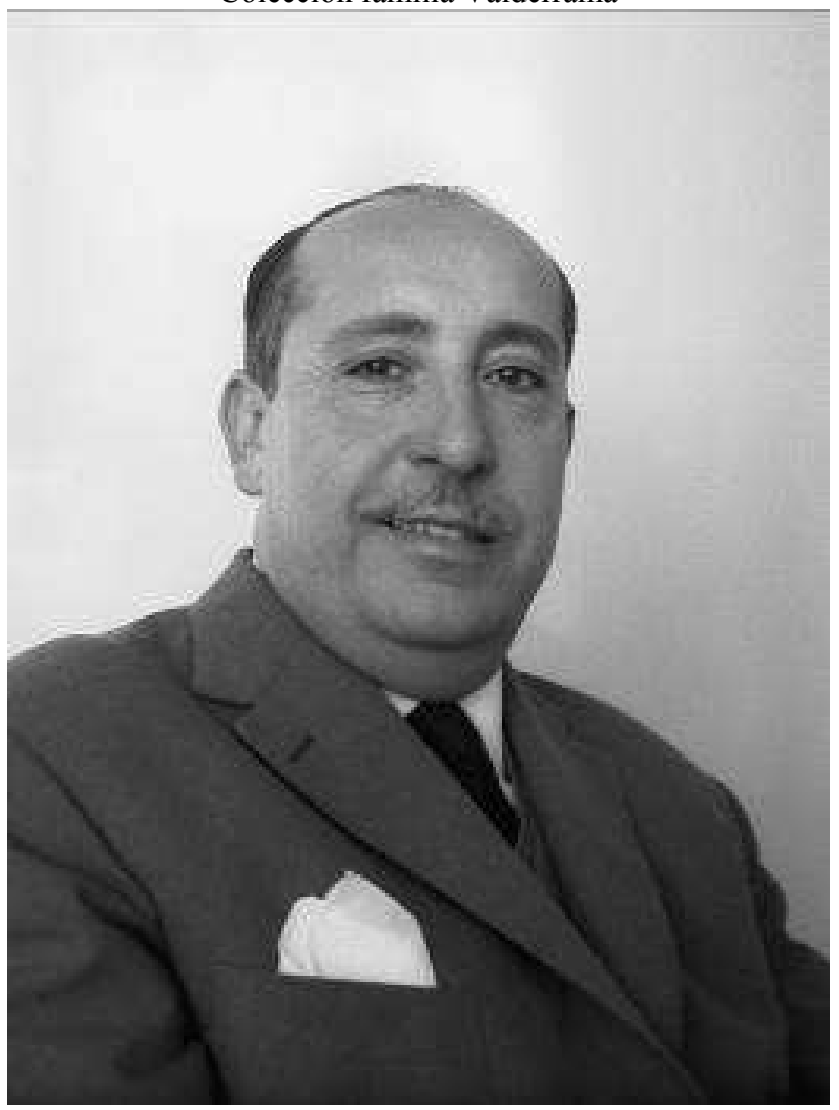


Finalizado el Protectorado en 1956, Valderrama se instaló en París como funcionario de la UNESCO, colaborando en proyectos relacionados con Túnez y América, y en 1982 fue nombrado Secretario de la Comisión Española de Cooperación con la UNESCO, en la que dirigió su revista y publicó Historia de la UNESCO (1995). Presidió y dirigió también varias entidades de prestigio, entre ellas la Asociación Española de Orientalistas, y fue galardonado con la Gran Cruz de Alfonso X el Sabio y la Encomienda de Número de la Orden de la Mehdauía de Marruecos. Donó parte de sus documentos a la Biblioteca Islámica en 2004, catalogados con la signatura específica VAL. El legado consta de material impreso, la denominada "Miscelánea", manuscritos y fotografías:

a) Material impreso. Compuesto por monografías, separatas y números sueltos de revistas. Suman 707 unidades, referenciadas en el número 181 de Cuadernos de la Biblioteca Islámica (2012); entre ellas los 55 libros publicados por Valderrama con la obra por excelencia: Historia de la acción cultural de España en Marruecos (1912-1956), donde se reproduce parte de las fotografías conservadas en su archivo particular.

b) "Miscelánea". Este material consta de 60 volúmenes, la mayor parte sobre el Protectorado (1913-1956) y con predominio de recortes de prensa, ordenados cronológicamente y tomados de Heraldo de Marruecos, El Telegrama del Rif (Melilla), Democracia de Tánger, El Faro de Ceuta o Unidad Marroqui de Tetuán.

c) Manuscritos. Dos documentos de mediados del siglo XIX (sig. 4M-14 y 4M-15). Ambos dedicados a Fernando Valderrama el 11 de agosto de 1950 por el Vice-Chej del Instituto Islámico Superior de Tetuán, encuadernados en cuero de época. El primero contiene 15 modelos de cartas (tinta negra y roja) y el segundo varios libros relacionados que incluyen viajes, ciudades y tradiciones.

d) Fotografías. Este conjunto documental es el que se analiza a continuación. Se trata de más de novecientas fotos de diversas temáticas y realizadas por varios autores. Parte de la memoria histórica del Protectorado se encuentra en las imágenes del legado Valderrama.

En septiembre de 2012 la Biblioteca Islámica inició el proyecto de catalogación de la colección de fotografías del legado Valderrama aprovechando que CISNE permitía incorporar la imagen digital a la descripción bibliográfica. La colección resulta relevante por su amplia y representativa selección de fotógrafos, así como por su testimonio sobre la acción cultural y educativa española en el Protectorado (figura 2). Toda la colección fue digitalizada y volcada en la web, asociada a su catalogación descriptiva, lo que permite su conservación y difusión. Como 
ejemplo de la colaboración interinstitucional y de cooperación, se incorpora una selección de la colección de fotos a la exposición digital organizada por la Biblioteca Virtual de Andalucía en 2014 que se denominará "Dos culturas, un mismo paisaje. Imágenes compartidas de españoles y marroquíes (1860-1956)".

Algunas fechas: recepción del legado (2004), elaboración de la bibliografía con todo lo catalogado (2012), inicio de la catalogación del fondo fotográfico aprovechando las funcionalidades de Millennium-Cisne (2012-2013), difusión mediante artículos en Awraq (2013) y asistencia al congreso de RIMAR (Granada 2012 y la participación en una publicación colectiva que se editará en 2014). Se solicita la cesión de derechos de reproducción en algunos fondos para ilustrar el número especial de la revista Awraq y el libro El Protectorado español en marruecos: la Memoria trascendida (publicado por Iberdrola y anotado en bibliografía) y también para ser expuestos durante seis meses (entre junio de 2014enero de 2015) en el Musac de León en la exposición temporal "Colonia Apócrifa". Todo ello permite albergar la esperanza de desarrollar proyectos más amplios y ambiciosos, como la cooperación institucional con la Biblioteca Nacional de España.

Figura 2. Archivo fotográfico Tetuán. Foto García Cortés. Álbum 4

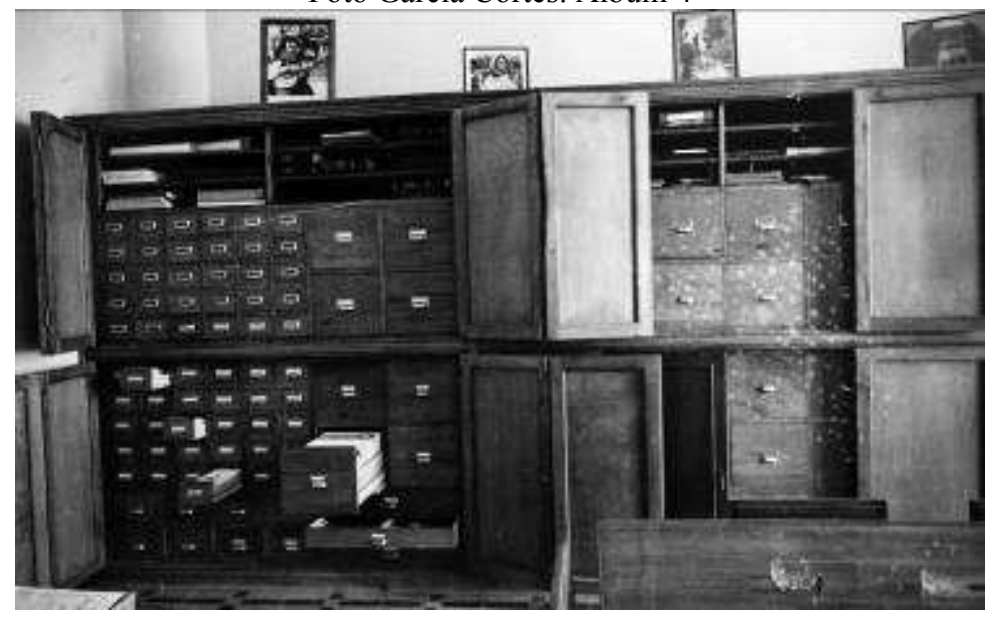

\section{LA FOTOGRAFÍA EN EL PROTECTORADO}

Durante los más de cuarenta años de Protectorado (1912-1956) la fotografía tuvo un desarrollo extraordinario como ya ha quedado reflejado en el estudio de Gómez Barceló: "Desde 1913 hasta 1928, está dedicada en el campo de la prensa a 
cubrir las noticias y a mostrar el trabajo realizado para europeizar las poblaciones ocupadas, mientras que el profesional de estudio, sin dejar de completar sus ingresos con las corresponsalías gráficas, se dedica a atender las demandas del público, ya sean fotografías destinadas a documentos públicos, ya lo fueran para el ámbito familiar o social" (Gómez Barceló, 2007: 61).

La relación de autores entre comienzos del siglo XX y la guerra civil es amplia: en Tetuán trabajaron José Ruiz, Luna, Sansó y Pereira, Beringola, Calatayud, Alberto, Grecia, Zenitram, Martínez y González, Arbona, Alcaraz y Foto América; en Larache Ángel G. de Castro, Tadey, Gafer y Diodoro; en Alcazarquivir Luis Ricart; en Arcila Rómulo de Hevia y Herminio Blanco; en Nador Félix Solís; en Villa Sanjurjo José Lacalle; en Xauen José Moreno, y en Tánger José Blanco, Zarzuela, Seca y Vicente Oltra.

Entre 1909 y 1915 estuvo activo en la zona José Ortiz Echagüe (Guadalajara, 1886-Madrid, 1980), uno de los más reconocidos y prestigiosos fotógrafos españoles, cuya obra contiene temas militares, retratos, paisajes y costumbres de carácter documental. Menos conocido fue Antonio Gavilán, presidente de la Asociación Obrera con estudio en Larache en 1931, quien tuvo como secretario en 1934 a Francisco Souza, uno de los reporteros de la agencia Mayo.

Coincidiendo con la creación del Protectorado se estableció en Ceuta José Calatayud Aznar (Paiporta, Valencia 1888-Tetuán, 1957), que tras realizar el servicio militar trabajó en el estudio de José G. Vázquez, y junto a su hermano Manuel abrieron negocio en el que realizaron, además de retratos, reportajes urbanos, tomas de paisajes y temas costumbristas. Tuvieron también sucursal en Tetuán y editaron tarjetas postales.

Entre 1921 y 1925 los reporteros de los grandes periódicos fueron enviados para cubrir los escenarios de la guerra, entre ellos José Díaz Casariego, Alfonso Sánchez Portela y Lázaro, del que se conservan originales en formato tarjeta postal en la agencia Efe. Los éxitos de estos reporteros llenaron las páginas de los diarios y revistas, y sus imágenes impactaron en la opinión pública. Gómez Barceló recoge los fotógrafos que tuvieron negocio hasta la guerra civil, tomando como fuente los anuarios y guías oficiales de Marruecos y del África española (Gómez Barceló, 2007: 63), y entre ellos a Bartolomé Ros (Murcia, 1906-Madrid, 1974), aprendiz en el estudio del fotógrafo Calatayud en Ceuta y con negocio propio desde 1929. Fue colaborador de Abc, Blanco y Negro y Mundo Gráfico entre 1918 y 1931, y en la década de los sesenta se trasladó a Madrid donde fundó el laboratorio Ros Fotocolor.

En 1940 llegó temporalmente a Tetuán Nicolás Muller (Oroshaza, Hungría, 1913- Llanes, 2000) para documentar la entrada del nuevo Jalifa en esa ciudad. Un año más tarde huyó de su país de origen para instalarse en Tánger, donde permaneció entre 1941 y 1947. Conoció a Fernando Vela, secretario de Ortega y Gasset, que le facilitó la colaboración en el diario España y en las revistas África y Mundo. La Alta Comisaría de España en Marruecos le encargó reportajes sobre 
las ciudades de Tetuán, Larache, Tánger y Melilla. En 1944 ilustró Tánger por el Jalifa, y en 1947 Estampas marroquies (1947). Ese año viajó a Madrid, donde frecuentó a los intelectuales de la Generación del 98 y abrió estudio. El primero de los libros de Muller fue el reportaje de un acto oficial, publicado como propaganda del evento, impreso en huecograbado y con alta calidad. Se trata de una obra institucional, promocional, propagandística y turística, editada por el Instituto de Estudios Políticos, que según Gil Benumeya era el "organismo oficial de la España renovada que con más empeño y continuidad coordina, articula e impulsa los valores y calidades de los territorios que España posee o protege en suelos berberiscos y suelos coloniales". En el segundo, se reprodujeron un centenar de fotos de paisajes, edificios, tipos y costumbres populares que reflejan la cultura del Protectorado (una copia de estas fotos, retrato de un artesano, se conserva en los álbumes de Valderrama).

También colaboraron con la prensa, aunque su función fue documental y no periodística, Vicente Zubillaga y Antonio Calvache, ambos instalados en Tánger aunque ninguno de los dos aparece registrado en los anuarios de la revista especializada Sombras en los años cuarenta. La actividad de Zubillaga se documenta en la primera mitad del siglo XX, recorriendo todo el país para captar vistas de ciudades y pueblos, por lo que su obra se encuadra en el género documental. En el año 1934 vendió parte de su colección de negativos $(6 \times 7 \mathrm{~cm})$ a la editorial Espasa-Calpe, fondo con el que se ilustraron las publicaciones de la empresa, en especial las enciclopedias y las magnas colecciones Summa Artis e Historia de España. El 25 de octubre de 1947 inauguró la exposición "Fotografías de Arte de Marrueco" en la Dirección General de Marruecos y Colonias de Madrid, para la que preparó sesenta temas. En ese periodo produjo, en el local del número 2 de la calle Lafayette de Tánger, las ilustraciones para guías, folletos y publicaciones turísticas de la posguerra. En 1951 publicó el libro Tánger con 196 fotos divididas en cuarenta apartados entre los que destacan "Así es Tánger", "Grupo Escolar de España" y "Radio Internacional". Tras la desaparición del Protectorado en 1956 realizó trabajos para el diario $A b c$ y con la Oficina de Turismo de Tánger.

Antonio Calvache (Córdoba, 1896-Madrid, 1984) abrió su estudio en un viejo almacén de ropa situado en la calle Shiagins 46 de Tánger a comienzos de los años cuarenta, coincidiendo con la ocupación de la ciudad por las tropas franquistas durante la Segunda Guerra Mundial. Se instaló en el Hotel Niza y contactó con el fotógrafo local Francisco López Alba, con galería en el número 10 de la calle Tunjín. El negocio estuvo abierto al menos una década y en los años cincuenta llegó a dirigir cinco galerías: Tánger (Shiagins 46 y Goya 7), Ceuta (Soberanía Nacional 32), Gibraltar (Main Street 68-70) y Madrid (Carrera de San Jerónimo 18). En la década de los sesenta vivió en París y regresó a Madrid para instalarse en el número 49 de la calle Atocha. 
El elenco de autores se completa con aquellos que realizaron imágenes para su distribución en formato tarjeta postal, siguiendo los pasos de Calatayud. La empresa editora por excelencia en el primer tercio del siglo XX fue Hauser y Menet, y posteriormente Loty, Roisin o Rubio, entre otros, produjeron cientos de imágenes que aumentaron el negocio de la fotografía en el norte de África (figuras 3 y 4 )

Figura 3. Tetuán, 1954. Foto Roisin

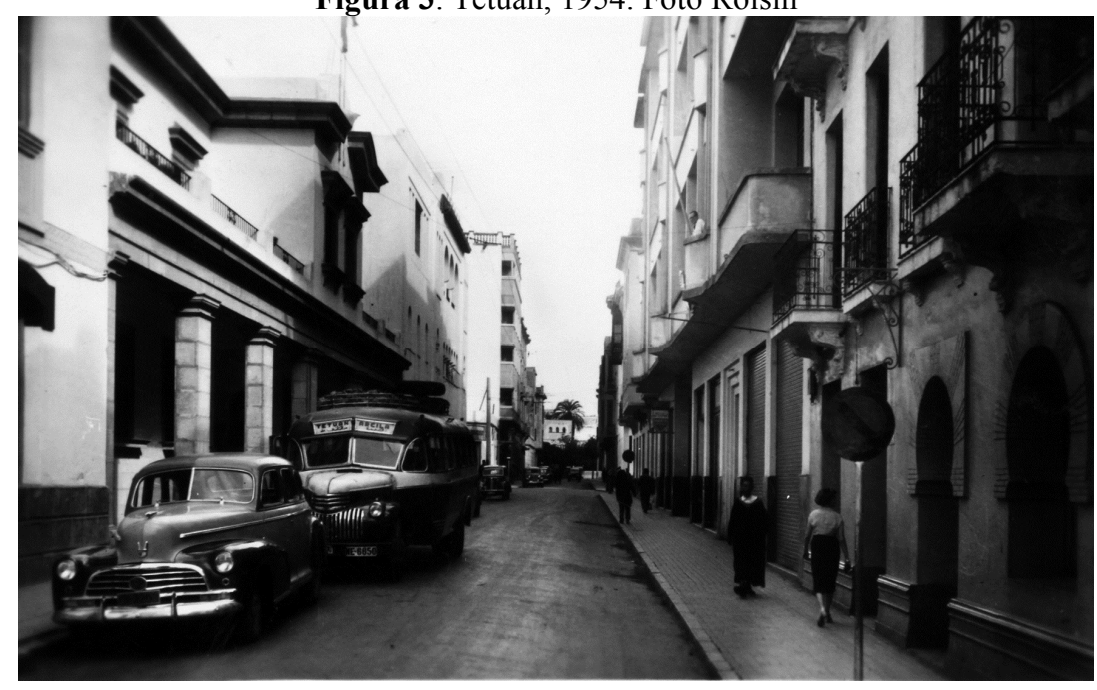

Figura 4. Ceuta, 1954. Foto Rubio

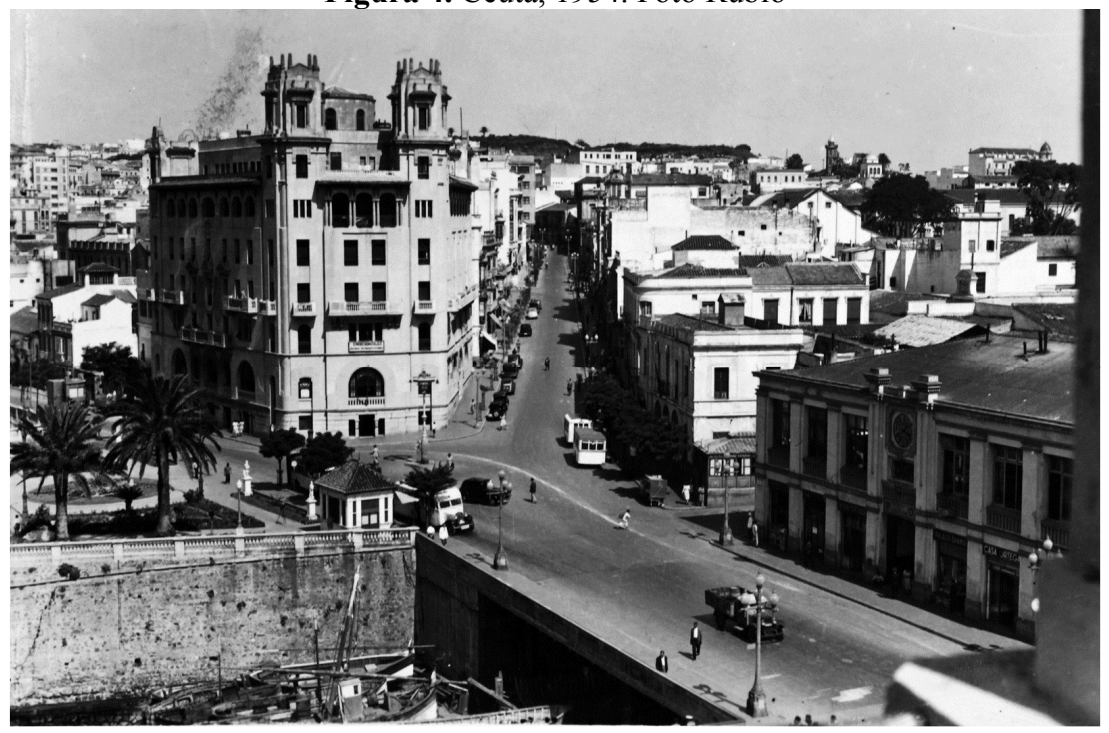


Fuente excepcional para conocer la actividad fotográfica en el Protectorado en la última década (1946-1956) son los anuarios de la revista Sombras (Tabla 1), editados en 1946 y 1948, y los de la editorial Bailly-Baillière. Sombras, la única publicación especializada en la materia durante la posguerra, recogió 54 profesionales con sede en siete localidades: Alcazarquivir, Ceuta, Larache, Melilla, Tánger, Tetuán y Villa Sanjurjo. La mayor actividad se desarrolló en Melilla, con 33 entidades censadas $(60 \%)$, seguida de Ceuta con 7 (12\%), Tetuán con $6(11 \%)$, y Larache y Tánger con 3 (5,5\%), mientras que Alcazarquivir y Villa Sanjurjo contaron con un solo estudio. Los fotógrafos en activo fueron varios más considerando a los profesionales que trabajaban para las instituciones oficiales y los medios de comunicación. El elevado número de negocios en Melilla es una muestra de la intensa actividad económica en la zona.

Por otra parte debemos señalar a los proveedores de material y artículos, entre los que se encontraban Calatayud (Figura 5 y 6) y Ros en Ceuta; Ros, Diodoro García, Navarro y Ulzurrun en Larache; Emilio Lacalle, Vicente Martínez y Manuel Villa en Melilla; Ayuso-Sánchez Aranda, Eroty, Calatayud y Ros en Tetuán.

Figura 5. Tetuan, h. 1940. Foto Calatayud

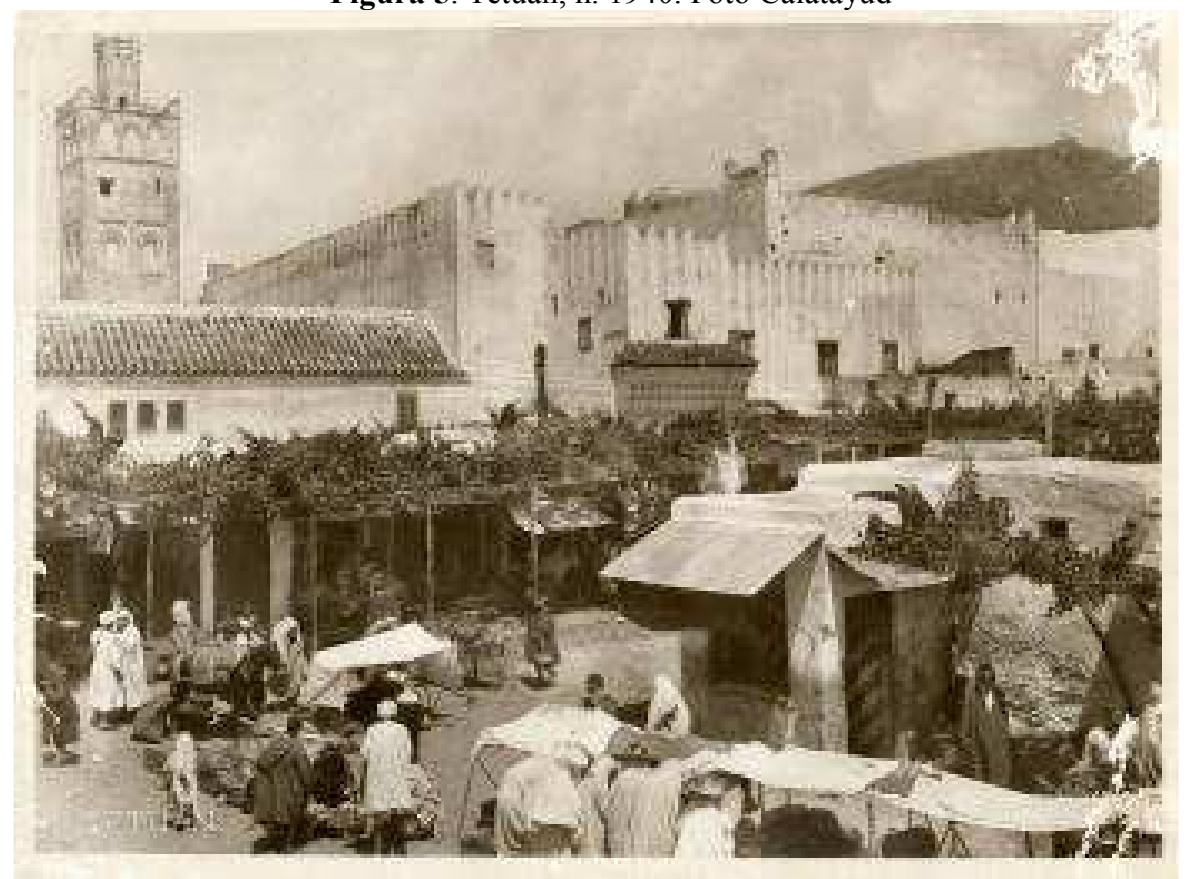


Tabla 1. Fotógrafos del Protectorado (1946-1948) Fuente: Anuarios de la revista Sombras

\begin{tabular}{|l|l|l|}
\hline \multicolumn{1}{|c|}{ LOCALIDAD } & \multicolumn{1}{|c|}{ NOMBRE } & \multicolumn{1}{c|}{ DIRECCIÓN } \\
\hline ALCAZARQUIVIR & Ricart, Viuda de L. & - \\
\hline CEUTA & Arbona, Salvador & Duarte, 3 \\
\hline & Bernal, José & Primo de Rivera, 4 \\
\hline & Calatayud & Camoens, 16 \\
\hline & Encomienda, Francisco & Falange Española, 55 \\
\hline & Merlo Manzano, Fernando & Falange Española, 8 \\
\hline & Pérez Villarino, Francisco & Tte. Coronel Gautier, 35 \\
\hline & Rubio, Francisco & Falange Española, 32 \\
\hline & García, Diodoro & \\
\hline & Navarro & \\
\hline & Ulzurrum & \\
\hline & Alpuente Cabo, Luis (1) & Margalló, 6 \\
\hline & Bergano Padilla, José & O'Donnell, 29 \\
\hline & Campos Ruiz, Juan & Canteras P. Pérez, 17 \\
\hline & Carmona Márquez, Santos & Honduras, 24 \\
\hline & Cobacho, Antonio & Ex. Camellos, 1 \\
\hline & Exuperio España, Narciso & Rafael M. de Labra, 4 \\
\hline & Fernández Pascual, Antonio & Carmen, 14 \\
\hline & García Pérez, Antonio & Frente a Cuartel Sanidad \\
\hline & Gómez Pérez, Antonio & $1^{\circ}$ de Mayo, 8 \\
\hline & Gómez, Ricardo & Ejército Español, 5 \\
\hline & Gutiérrez Jiménez, Narciso & Aragón, 26 \\
\hline & $\begin{array}{l}\text { Hernández Sánchez, } \\
\text { Antonio }\end{array}$ & Cuatro Vientos, 6 \\
\hline & Herrero Reina, Cristóbal & Álvaro Bazán, 30 \\
\hline & Jurado Reyes, Manuel & Explanada Badía, 17 \\
\hline & Lacalle, Emilio & Cándido Lobera, 3 \\
\hline & López Pérez, Alfonso & Reina Regente, 79 \\
\hline & López Pérez, Francisco (2) & García Cabrelles, 9 \\
\hline & López Piñeiro, Manuel & O'Donnell, 9 \\
\hline & Luque, Isabel (Foto Luque) & General Pareja, 9 \\
\hline & Martínez Martínez, José & África, 35 \\
\hline & Palancarejo Sánchez, Ángel & - \\
\hline & Pérez Romero, Esteban & Salamanca, 27 \\
\hline & Peris Mesa, Julio & Barcelona, 35 \\
\hline & Quesada Yasi, Francisco & Jacinto de Oval, 4 \\
\hline & Rodríguez Nicolás, José & A. Falcón, 14 \\
\hline & & \\
\hline & & \\
\hline & &
\end{tabular}




\begin{tabular}{|l|l|l|}
\hline \multicolumn{1}{|c|}{ LOCALIDAD } & \multicolumn{1}{|c|}{ NOMBRE } & \multicolumn{1}{c|}{ DIRECCIÓN } \\
\hline & Rua Serfaty, José & Barceló, 29 \\
\hline & Ruiz Rambla, José & Ruiz de Sotomayor, 4 \\
\hline & Soria Romero, Miguel & Salamanca, 34 \\
\hline & Tudela, Juan & C. Seguí, 2 \\
\hline & Ucha, Emilio & Mar Pradera, 2 \\
\hline & Vallés, José & Avda. Generalísimo, 21 \\
\hline & Vera Franco, Miguel & Mallorca, 13 \\
\hline & Vicente Cabrera, Pedro & Ataque Seco, 67 \\
\hline TÁNGER & Alba (Francisco López) & Tujin, 10 \\
\hline & Tukker Th. S. & S.A.I. Jalifa \\
\hline & Venus & Las Once, 7 \\
\hline TETUÁN & Alba (Francisco López) & Generalísimo Franco, 26 \\
\hline & Alberto & Luneta, 91 \\
\hline & Fernández Cuadrajo, Juan & Calvo Sotelo, 8 \\
\hline & García Cortés, Francisco & Calvo Sotelo, 8 / \\
& & Sanjurjo, 14 \\
\hline & Moderna Foto & Plaza de José Antonio \\
\hline & Morales, J. A. & Primo de Rivera \\
\hline VILLA SANJURJO & Esperanza Foto & Rif \\
\hline
\end{tabular}

(1). Se estableció en 1947 o 1948 // $\quad$ (2). Sin estudio en 1948

El anuario Bailly-Baillière (tabla 2) de 1947 incluye solo 14 negocios, pero omite los de Melilla, lo que indica que los profesionales eran más o menos los mismos que los citados en los anuarios de la revista Sombras. En 1954, dos años antes de que terminara el Protectorado, los locales censados eran 31 (también sin los de Melilla), con un aumento muy considerable de 16 negocios, es decir casi el doble. Salvo excepciones, la mayor parte de los fotógrafos que figuran en el anuario de 1947 continuaban con su actividad en 1954. De los 31 autores referenciados, 13 realizaban su actividad en Tánger y 8 en Tetuán, ya que Cuadrado figura con estudio en Tetuán en 1947 y en Tánger en 1954. Además de éste, también Navarro cerró el negocio de Tetuán.

En los anuarios de Sombras con respecto a los de Bailly-Baillière de 1947 no figuran Rómulo Hevia (Arcila) y José Lacalle (Villa Sanjurjo). En 1954 los profesionales con negocio en Tánger experimentaron un aumento pasando de 3 a 14, mientras que en Tetuán y Larache se mantuvo la media de 3 en esos años. 
Tabla 2. Fotógrafos del Protectorado (1947 y 1954) Fuente: Anuarios Bailly-Baillière

\begin{tabular}{|c|c|c|c|}
\hline LOCALIDAD & FOTÓGRAFO & 1947 & 1954 \\
\hline ALCAZARQUIVIR & Ricart, Viuda de & $\checkmark$ & $\checkmark$ \\
\hline ARCILA & Rómulo de Hevia & $\checkmark$ & $\checkmark$ \\
\hline \multirow[t]{3}{*}{ LARACHE } & Aguilera & & $\sqrt{ }$ \\
\hline & Navarro & & $\sqrt{ }$ \\
\hline & García, Diodoro & & $\checkmark$ \\
\hline \multirow[t]{14}{*}{ TÁNGER } & Alba (Francisco López) & $\checkmark$ & $\sqrt{ }$ \\
\hline & Blasco & & $\checkmark$ \\
\hline & Conti & & $\checkmark$ \\
\hline & Cuadrado & & $\sqrt{ }$ \\
\hline & Fernández Cuadrado & & $\checkmark$ \\
\hline & Klingenmeyer & & $\checkmark$ \\
\hline & Leka & & $\sqrt{ }$ \\
\hline & Mike & & $\checkmark$ \\
\hline & Photomatón & & $\checkmark$ \\
\hline & Rex & & $\checkmark$ \\
\hline & Seca & & $\checkmark$ \\
\hline & Tukker & $\checkmark$ & $\checkmark$ \\
\hline & Ulzurrum & & $\sqrt{ }$ \\
\hline & Venus & $\checkmark$ & $\sqrt{ }$ \\
\hline TARGUIST & Cardeñoso & 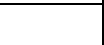 & $\sqrt{ }$ \\
\hline \multirow[t]{9}{*}{ TETUÁN } & Alba (Francisco López) & $\checkmark$ & $\checkmark$ \\
\hline & Alberto & $\checkmark$ & $\sqrt{ }$ \\
\hline & Calatayud & $\checkmark$ & $\checkmark$ \\
\hline & Cuadrado & $\sqrt{ }$ & \\
\hline & García Cortés, Francisco & $\checkmark$ & $\sqrt{ }$ \\
\hline & Moderna & $\checkmark$ & $\checkmark$ \\
\hline & Morales & $\checkmark$ & $\sqrt{ }$ \\
\hline & Navarro & $\sqrt{ }$ & \\
\hline & Ros & & $\checkmark$ \\
\hline TORRES DE ALCALÁ & Vaca, Antonio & & $\checkmark$ \\
\hline \multirow[t]{2}{*}{ VILLA SANJURJO } & Fox & & $\sqrt{ }$ \\
\hline & Lacalle, José & $\checkmark$ & $\checkmark$ \\
\hline
\end{tabular}


Figura 6. Tetuán, h. 1940. Foto Calatayud

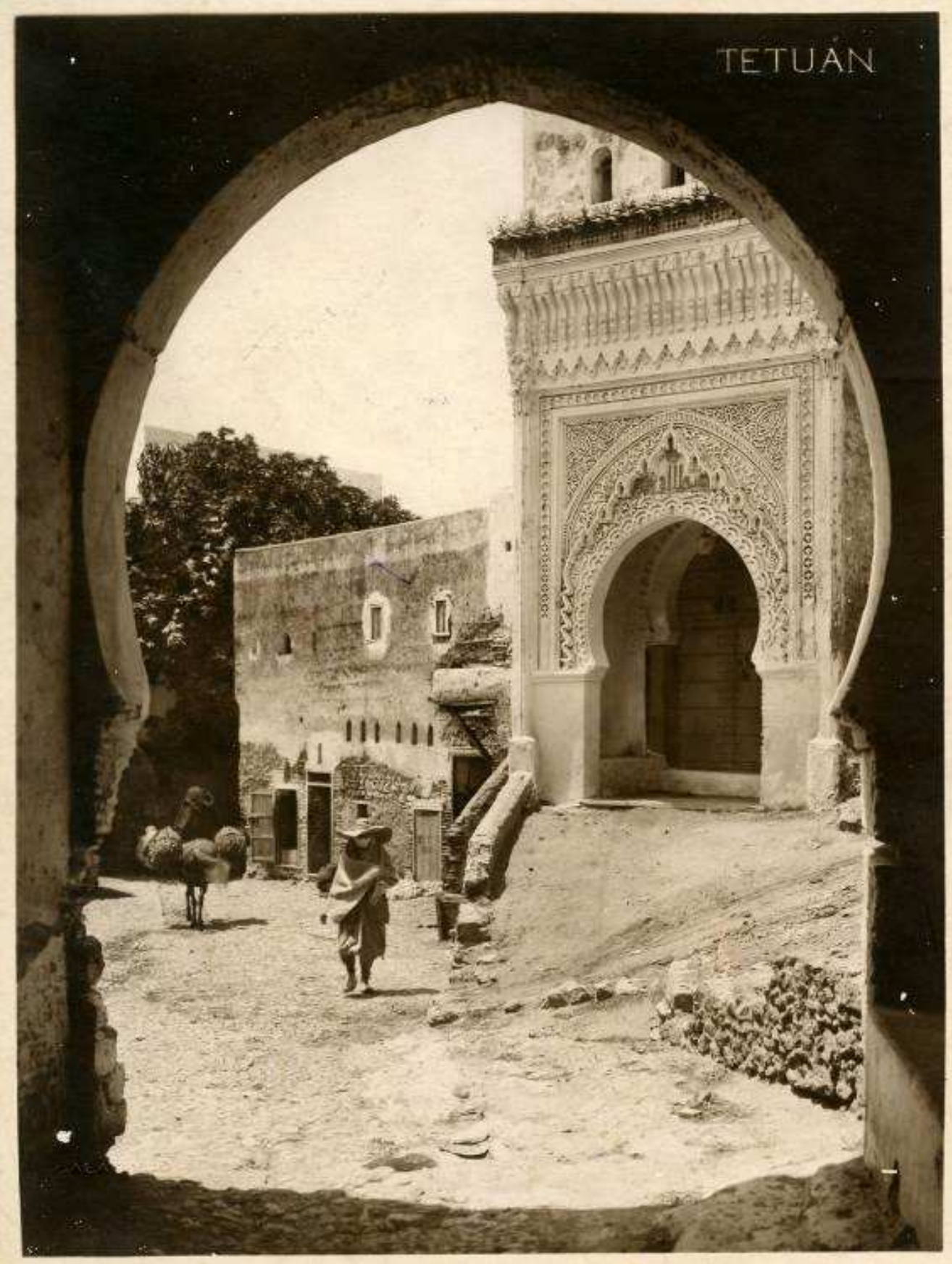




\section{EL FONDO FOTOGRÁFICO VALDERRAMA}

Las fotos del legado Valderrama se conservan en 10 álbumes (tabla 3). Los cinco primeros contienen los 428 originales utilizados para ilustrar Historia de la acción cultural de España en Marruecos (1912-1956), obra del autor ubicada en Tetuán en 1956; el sexto álbum contiene 137 fotos de actos oficiales, personalidades y edificios; el séptimo 68 imágenes de la ciudad mauritana de Walata, y vistas de Siria, Líbano y Tailandia; en el octavo se recogen 64 temas de Tetuán; en el noveno se recopilan 128 imágenes diversas de Melilla, varias fuentes de Tetuán y reproducciones de inscripciones árabes; y el décimo está dedicado esencialmente a fotografías (112) de las inscripciones en santuarios y cementerios islámicos de Tetuán, con la peculiaridad de que contiene material de archivo (transcripciones y traducciones de las inscripciones, permisos para fotografiarlas, etc.).

Tabla 3. Inventario de los álbumes fotográficos

Fuente: Carmen Sánchez de Molina Rampérez (AECID)

\begin{tabular}{|c|c|r|l|}
\hline ÁlBUM & SIG. & DOCS & \multicolumn{1}{c|}{ CONTENIDO } \\
\hline 1 & VAL-791 & 102 & $\begin{array}{l}\text { Copias publicadas en Historia de la acción cultural de } \\
\text { España en Marruecos (1912-1956), }\end{array}$ \\
\hline 2 & VAL-792 & 72 & Idem \\
\hline 3 & VAL-793 & 83 & Idem \\
\hline 4 & VAL-794 & 88 & Idem \\
\hline 5 & VAL-795 & 83 & Idem \\
\hline 6 & VAL-796 & 137 & $\begin{array}{l}\text { Copias no publicadas en } H^{a} \text { de la acción cultural de } \\
\text { España en Marruecos }\end{array}$ \\
\hline 7 & VAL-797 & 68 & $\begin{array}{l}\text { Fotografías de Walata (Mauritania), Tailandia, Siria y } \\
\text { Líbano }\end{array}$ \\
\hline 8 & VAL-798 & 64 & $\begin{array}{l}\text { Personalidades y centros culturales en Tetuán, } \\
\text { Marruecos (Escuelas, residencias, museos) }\end{array}$ \\
\hline 9 & VAL-799 & 128 & $\begin{array}{l}\text { Fotos/postales de Melilla, serie-postal del Rif, postales } \\
\text { satíricas. Copias de Inscripciones árabes de Tetuán y El } \\
\text { culto a las fuentes en Tetuán }\end{array}$ \\
\hline 10 & VAL-800 & 112 & $\begin{array}{l}\text { Fotografías y textos sobre santuarios y cementerios de } \\
\text { Tetuán }\end{array}$ \\
\hline
\end{tabular}

El conjunto documental ofrece una visión global de la cultura en el norte de África a través de las instituciones y los eventos públicos: educación, prensa, música, bibliotecas, costumbres, etc. La descripción general de los contenidos de cada uno de los álbumes nos lleva de lo universal a lo particular, con información del fondo y de la forma, así como de la autoría, objetivos todos del estudio que nos ocupa. 


\subsection{ANÁLISIS Y VALORACIÓN}

Se detallan a continuación los contenidos con especial atención a los autores de las imágenes (tabla 4), con el fin de aportar nuevos datos sobre la labor de los fotógrafos españoles en el Protectorado. Las imágenes se datan entre los años 1940 y 1956, distribuidas entre los diez álbumes.

\section{ÁlBum 1}

Contenido diverso: retratos de personajes (diplomáticos, militares, El Jalifa, etc.); edificios públicos relacionados con la educación y la cultura (figura 7); reproducción de certificados de enseñanza, y actividades escolares. Destacan entre los originales los retratos de Franco sobre el original de Alfonso (foto 2 página 1, signatura VAL-791-1-2), Muley El Mendi Ben Ismail de Cuadrado (foto 1 pág. 2) o Ahmed Ben Mohamed (foto 1 página 4). Los formatos son pequeños $(3 \times 4 \mathrm{~cm})$ y medios $(7 \times 10$, y $8,5 \times 11 \mathrm{~cm})$, originales de época firmados en gran parte por García Cortés. Los papeles fotográficos son Agfa Brovira y Rapid, fabricados en los años cuarenta y cincuenta, más otros de mil puntos y de alto contraste. Los autores son los siguientes: Francisco García Cortés, Vicente Zubillaga (fotos científicas y documentales), Alberto (Tetuán), Diodoro García (Larache), Ulzurrun (papel de mil puntos y cortes dentados), Falarido, Imperio (Melilla), Ros (formatos 9x12 en papel sepia), Morales (Tetuán) y Virgilio.

Figura 7. Escuela organizada por las Intervenciones en la Uad Lace.

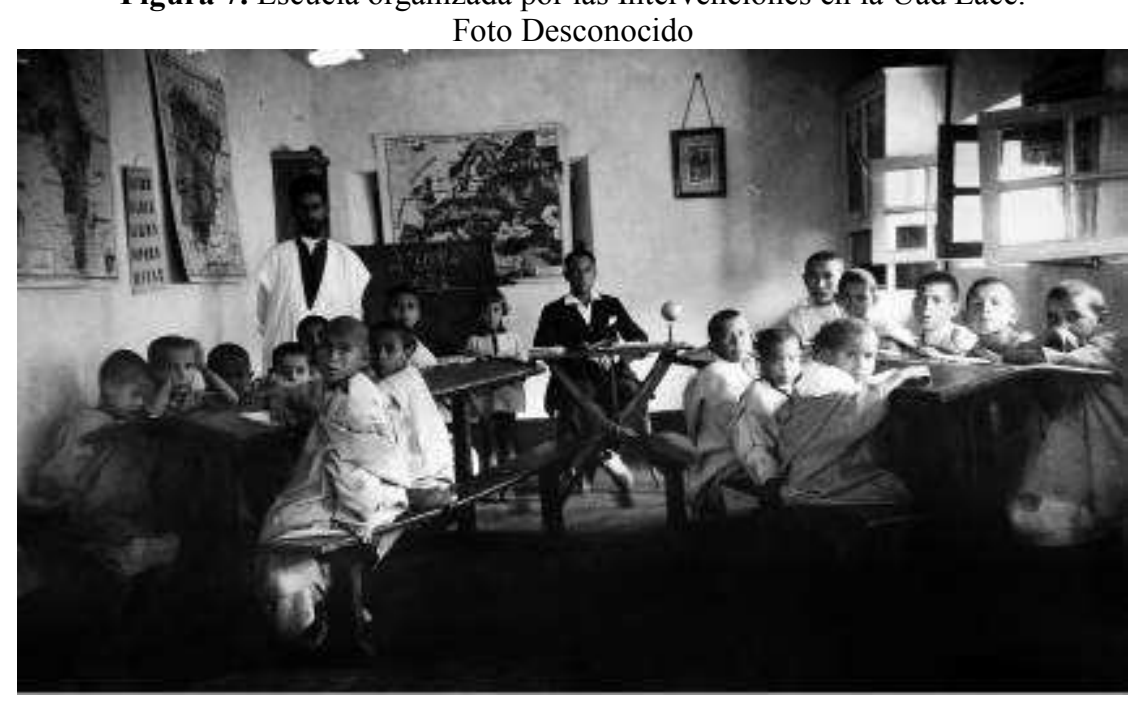




\section{ÁlBum 2}

El contenido se reparte en cinco grupos: retratos, grupos escolares (interiores y exteriores), escenas urbanas, espectáculos y reproducción de objetos. Los formatos son diversos, desde los $4 \times 5 \mathrm{~cm}$ de las fotos de carné hasta los 17x11, además de las tarjetas postales. El autor con mayor número de imágenes es García Cortés, cuyas fotos destacan por la perspectiva fuera de lo convencional y por el reportaje del pintor Bertuchi con Valderrama (figura 8). Por otra parte, no se limita a tomas tradicionales de los edificios sino que busca elementos humanos y objetos para las composiciones. También son de gran interés las escuelas de artes indígenas en Tetuán, con retratos en primer plano de los alumnos. Los sellos al dorso de las fotos de García Cortés son diversos: en los años cuarenta el apellido y la ciudad (Tetuán), y a partir de 1949 un óvalo dibujado a modo de paleta de pintor con letra inglesa y con la ciudad en versales $(3 \times 2 \mathrm{~cm})$. Un tercer modelo es la firma GCortés, calada en blanco a la derecha de los positivos. Otro fotógrafo es Ulzurrun, con positivos en papeles de mil puntos y cortes dentados. Completan los originales las obras de la Viuda de Ricart, con sede en Alcazarquivir, de papeles en tono cálido y formato tarjeta postal dentados en los bordes.

Figura 8. Entierro de Bertucchi. Foto García Cortés

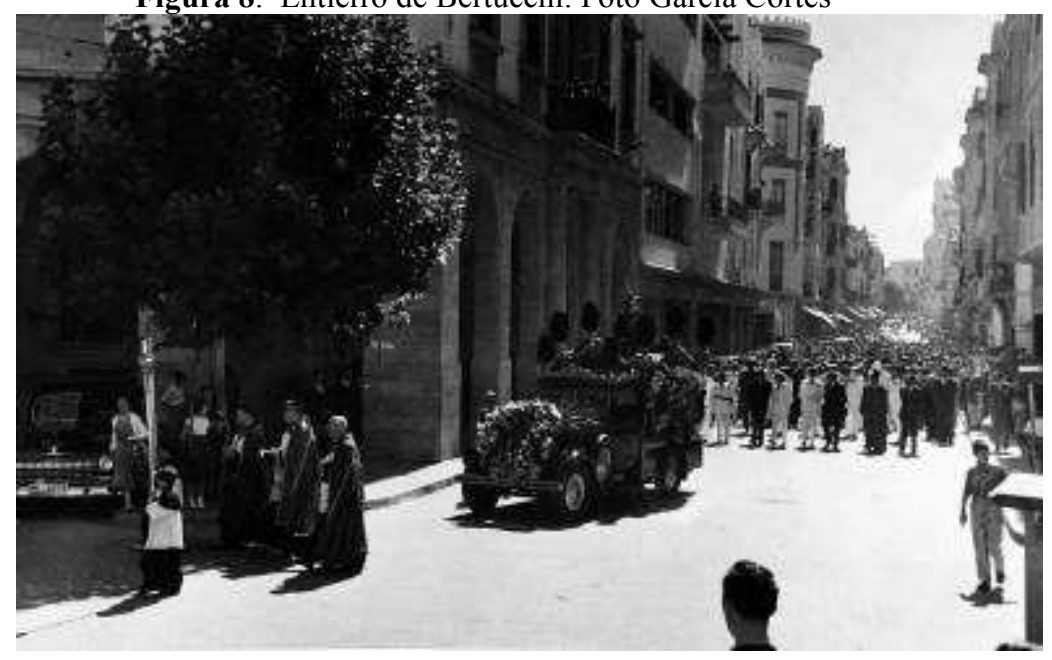

\section{ÁlBum 3}

Los motivos u elementos captados son edificios (interiores y exteriores) y retratos de militares. Las vistas son de la Escuela Politécnica de Tetuán, si bien muchas de ellas recortadas y por tanto sin la información completa. El autor es también Francisco García Cortés, que utilizó papeles Brovira de Agfa $(15 \times 20 \mathrm{~cm})$. Algunos positivos se presentan en papel de mil puntos y en formato tarjeta postal $(9 \mathrm{x} 12 \mathrm{~cm})$. En el conjunto se encuentran reproducciones de fotografias antiguas, 
realizadas por García Cortés, y destacan los excelentes positivos de Palacios sobre la Escuela Politécnica en formato $15 \times 20 \mathrm{~cm}$ (figura 9). Este autor firmó con la inicial de su apellido (P) y con el año. Otros autores son Ros (Ceuta y Tetuán), Cuadrado (Tetuán, tarjetas postales), Falarido, Manon (Tetuán), Morales (Tetuán) y Mancebo (Garibel 8, Granada).

Figura 9. Fachada escuela politécnica. Foto Palacios

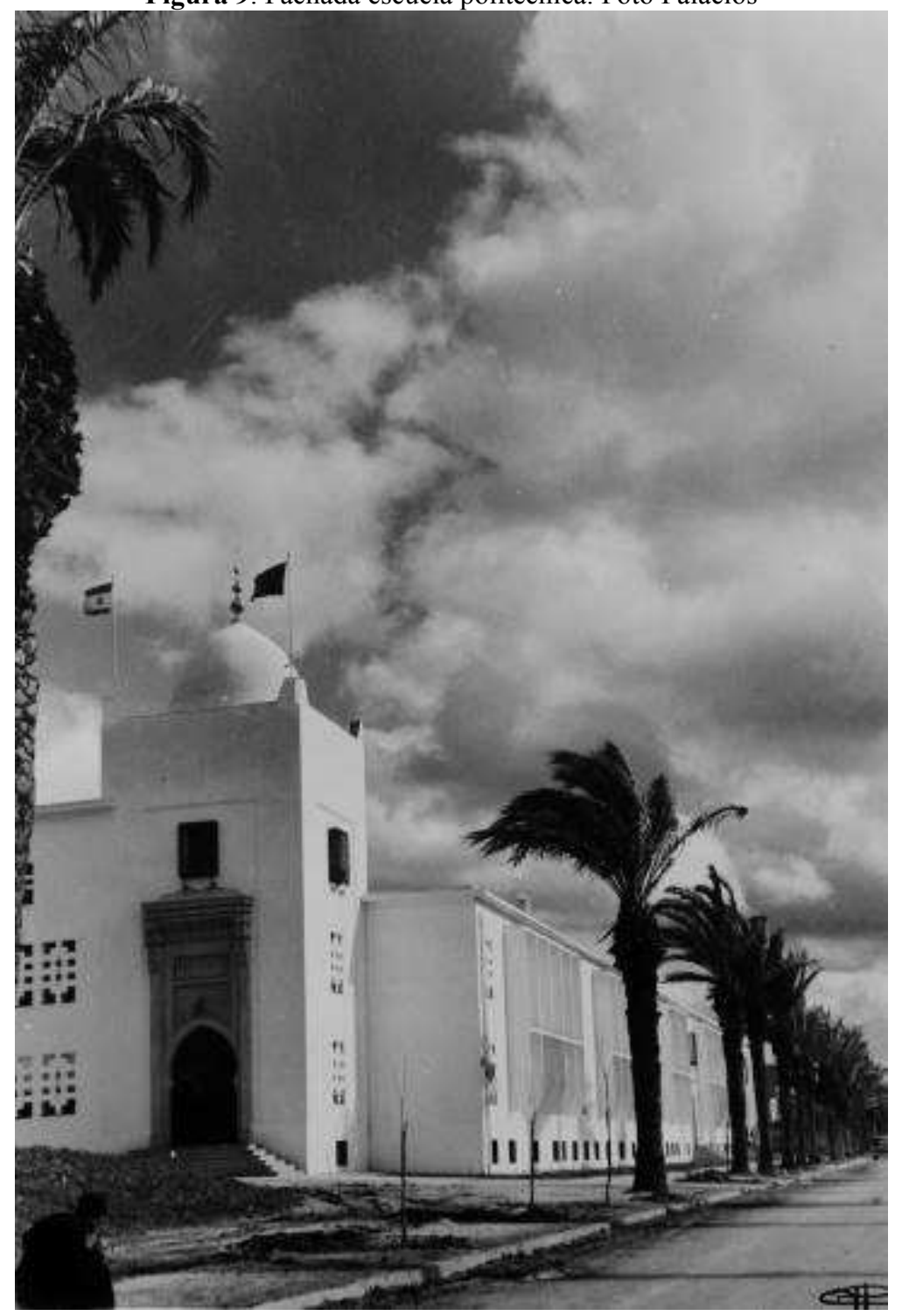




\section{ÁLBUM 4}

Contiene imágenes de la Oficina de Turismo y de los comercios de Tetuán en formato 10x15 cm, obras de García Cortés fechadas en 1956. Son de gran interés las fotografías de las instalaciones y la maquinaria del Diario de África (linotipias y rotativas), así como de la emisora Persa (1945), y los temas populares de carácter deportivo como el Atlético de Tetuán (figura 10). Se completan los documentos con vistas de palacios y edificios públicos, entre ellos el reportaje de García Cortés sobre museos marroquíes. De este autor son además los retratos de alumnos, las escuelas, las clases, los actos oficiales, los edificios, las exhibiciones culturales como la Feria del Libro (una decena de originales en formato 10x15 $\mathrm{cm}$ ), así como el reportaje de expediciones científicas con el retrato de Pelayo Quintero Atolauro. Por su calidad destacan los retratos de Sidi el Arabi el Jalib, fechado en enero de 1956, y el reportaje de la Biblioteca General de Tetuán (3), el Archivo General (2), la Hemeroteca (1) y el Archivo fotográfico (2), del que se observa claramente su distribución en uno de los positivos y que permite afirmar que se trataba de un gran fondo documental. El mueble muestra 30 cajones de madera en formato mayor, 18 en formato medio, 30 en menor en la parte inferior, otros 8 en formato medio y 2 planos.

Figura 10. El Atlético de Tetuán. Foto García Cortés

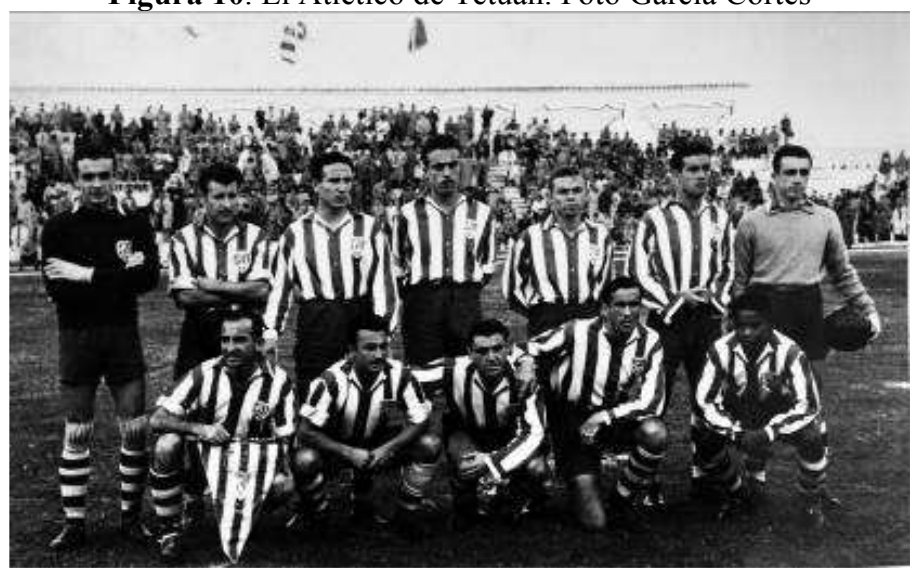

\section{ÁlBum 5}

Se caracteriza por la variedad de contenidos: vistas de Chauen y de Ketama, policía, retratos diversos, actos oficiales, edificios educativos, actuaciones, exposiciones escolares y reproducciones de fotos de principios del siglo XX. Destacan los retratos del pintor Bertuchi, del músico Jesús Guridi y del escritor José María Pemán. Así mismo es de gran interés la fotografía de la escuela Alfonso XIII en Tánger (figura 11), sin firma, en la que aparece el general Miguel Primo de Rivera con un grupo de franciscanos, alumnos del centro. Los autores de 
las fotos son García Cortés, Zubillaga (copias en papel Agfa Brovira con sello al dorso), Austin (excelente grupo escolar, 9 de julio de 1957), Calatayud y Morales.

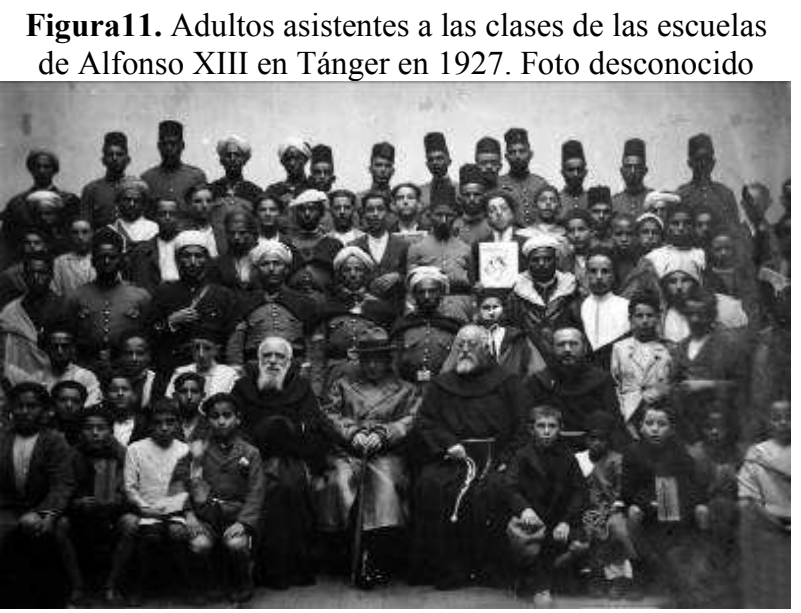

\section{Álbum 6}

Integra reproducciones de copias antiguas, retratos, piezas de arqueología, actos oficiales con la presencia de El Jalifa y el general García Valiño, la residencia de estudiantes marroquíes de Melilla (8 fotos) y grupos escolares de Alcazarquivir (11 fotos). Destacan por la belleza de las imágenes los campesinos de Yebala (figura 12), obra de Vicente Zubillaga en tono sepia y formato $13 \times 18$ $\mathrm{cm}$. Entre los soportes se encuentran papeles Leonar de la firma Nector. Los fotógrafos representados son García Cortés, autor de la mayoría de las fotos, el citado Zubillaga, Bartolomé Ros, Austin (tarjeta postal de los años treinta), Anavitare, Mancebo (Granada) y Antonio Vaca (Torres de Alcalá).

Figura 12. Campesinos de Yebala. Foto Zubillaga

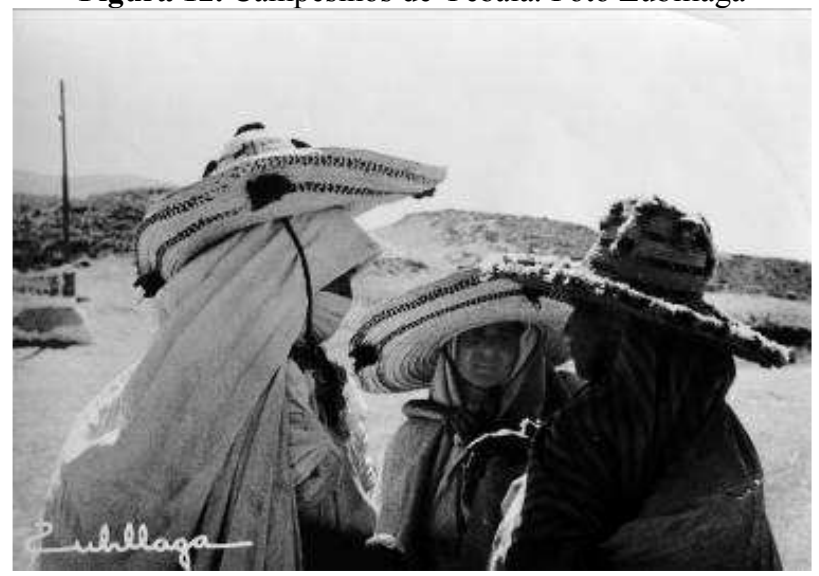




\section{ÁLBum 7}

Contiene una colección de 68 imágenes, 25 de ellas sobre tipos populares, arquitectura y decoración, más interesantes por su contenido que por su técnica $(20 \times 25 \mathrm{~cm}) ; 18$ fotos del Centro de Educación Fundamental (Tufec) en Tailandia (20x25 cm), y 25 fotos de paisajes de Tell Krim, Kafer Nasej, Kuneitra y Tell Antar $(13 \times 18 \mathrm{~cm})$, todas sin firma. Son fotografías de gran calidad probablemente positivadas para ser expuestas (figura 13). Algunas con información adjunta en cartel: "Los Reyes de Tailandia visitando el centro de Educación Fundamental (Tufec)", "Una ceremonia budista", etc.

Figura 13. Mujer preparando té.

Foto desconocido

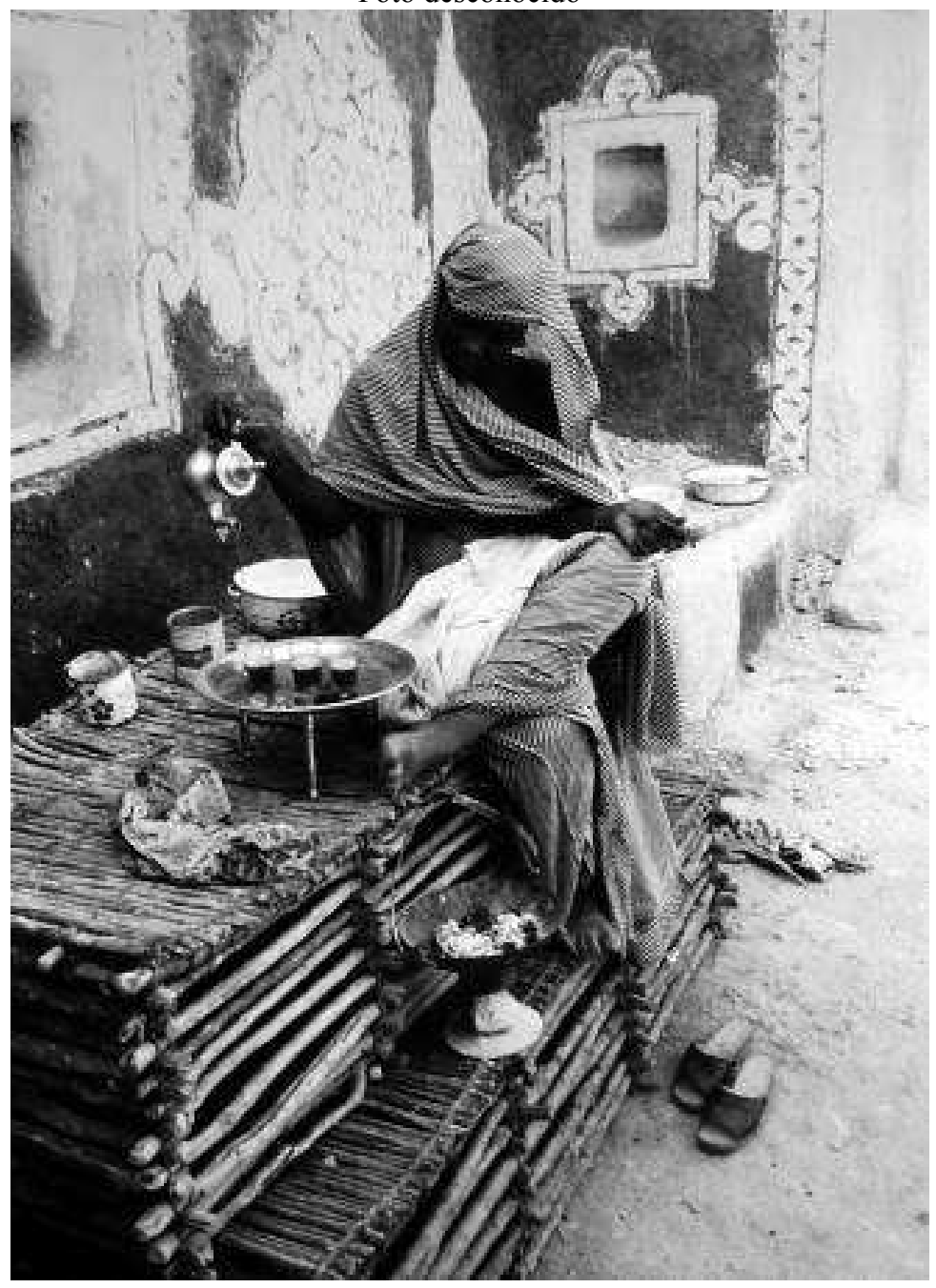




\section{Álbum 8}

Por un lado, contiene imágenes de gran calidad de la Residencia de Estudiantes Marroquíes (figura 14) en Tetuán (37) firmadas por Palacios (18x24 cm). De este mismo autor son las tomas de la Escuela Politécnica, positivadas en papel sepia, que se corresponden con copias de los álbumes 3 y 8 . Por otro lado, se completa el conjunto con las fotos de la Escuela de Artes Indígenas (4) por García Cortés y reproducciones de objetos de arte, más 4 fotos $(10 \times 15 \mathrm{~cm})$ de las cocinas y salón de recreo, sin firma. Son de interés también las fotografías del Grupo Escolar (10) de García Cortes y Ulzurrun.

Figura 14. Residencia de Estudiantes Marroquíes en Tetuán.

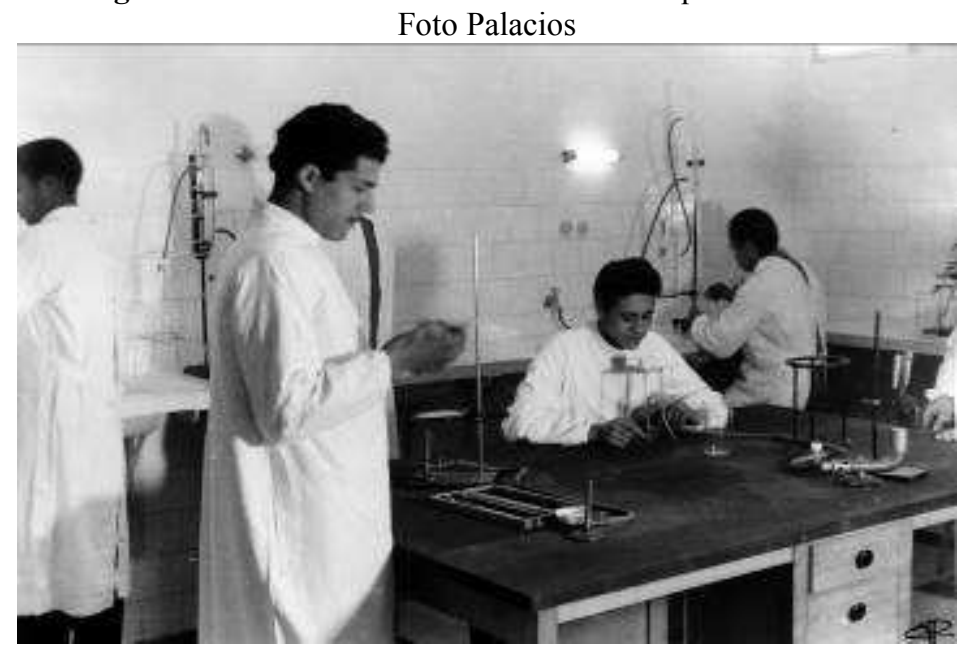

\section{Álbum 9}

Los originales se caracterizan por su diversidad. Encontramos fotografias de Melilla en diversos tamaños, en blanco y negro (dos en color). Se conservan también reproducciones de tarjetas postales (figura 15) en tamaño mayor (18x24 $\mathrm{cm})$ y algunos recortes de prensa. Se añade una reproducción del diario $E l$ Telegrama y un retrato de Cándido Lobera. Son muy interesantes dos tarjetas postales dobles, panorámicas de los barrios de El Real y El Hipódromo. Entre las tarjetas postales destacan 31 originales de la campaña del Rif, editados por Hauser y Menet, con las dramáticas escenas de Monte Arruit. Se añaden al conjunto 22 tarjetas de vistas ( 5 en color), y otras 12 de contenido satírico con dibujos de D. Mullor. Completan el álbum 24 fotografías de detalles de inscripciones por García Cortes $(13 \times 18$ y $20 \times 25 \mathrm{~cm})$ y 15 imágenes de Tetuán del mismo autor. 
Figura 15. Melilla Calle Prim.

Boix Hermanos de Melilla editores. Tarjeta postal

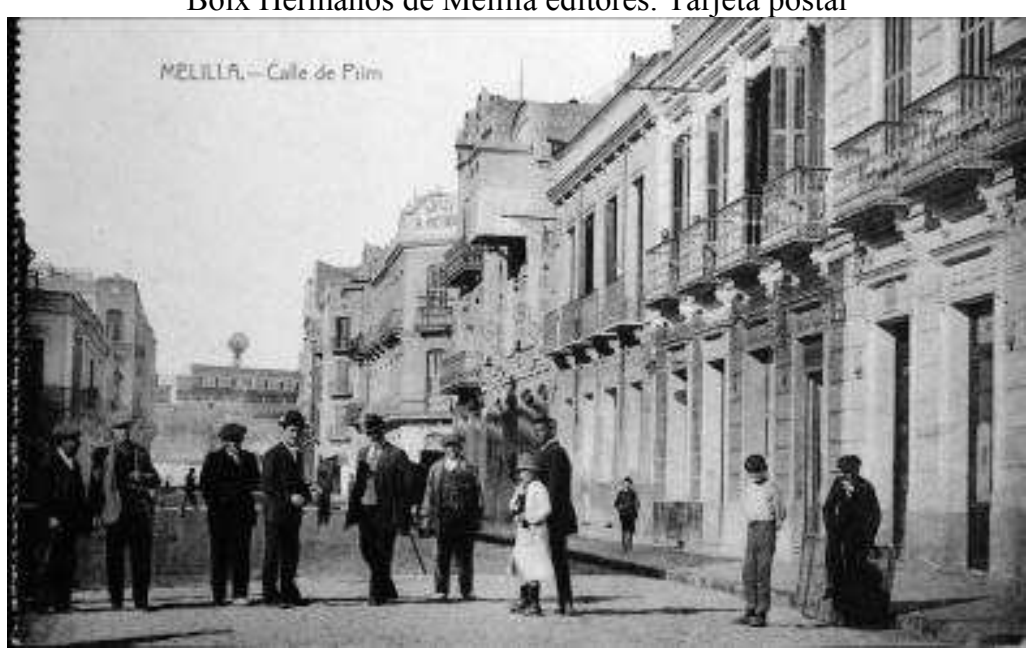

ÁlBum 10

Colección de fotografías $(13 \times 18 \mathrm{~cm})$ y textos de diversos tamaños sobre lápidas e inscripciones de Tetúan, fechadas en 1953 (figura 16). La mitad de las copias llevan al dorso el sello de Merino. Se trata de un encargo documental que presupone algún trabajo o estudio sobre el tema referido. Entre la documentación se encuentra un sobre vacío del fotógrafo García Cortés, con la dirección impresa en el exterior: calle Sanjurjo 14, Tetuán.

Figura 16. Mosaico Zawija al Wazaniya (Tetuán).Foto Merino

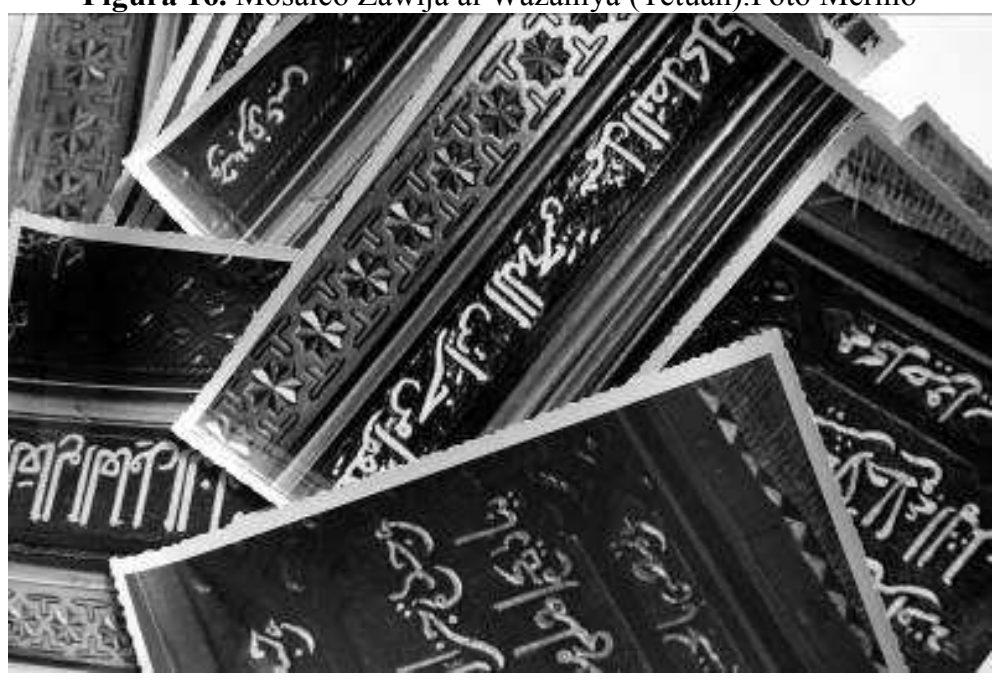


Tabla 4. Álbumes de Valderrama. Autores de las fotografías

Fuente: Elaboración propia

\begin{tabular}{|l|l|l|}
\hline FOTÓGRAFO & LOCALIDAD & ÁLBUM \\
\hline A. Foto & Tetuán & 4 \\
\hline Alberto & Tetuán & 1 \\
\hline Anavitare & & 6 \\
\hline Austin & Melilla & 5,6 \\
\hline Calatayud & Ceuta & 5 \\
\hline Calavero & & 3,8 \\
\hline Cuadrado & Tetuán & 1,3 \\
\hline Diodoro (García) & Larache & 1 \\
\hline Falarido & & 1,3 \\
\hline García Cortés, Francisco & Tetuán & $1,2,3,4,5,6,8,9$ \\
\hline Imperio & Melilla & 1 \\
\hline Mancebo & Granada & 3,6 \\
\hline Manon & Tetuán & 3 \\
\hline Merino & Tetuán & 10 \\
\hline Morales & Tetuán & $1,3,5$ \\
\hline Palacios & Tetuán & 3,8 \\
\hline Ricart, Viuda de & Alcazarquivir & 2 \\
\hline Ros, Bartolomé & Ceuta & $1,3,6$ \\
\hline Ulzurrun & Larache & $1,2,4,8$ \\
\hline Vaca, A. & Torres de Alcala & 6 \\
\hline Virgilio & & 1 \\
\hline Zubillaga, Vicente & Tánger & $1,5,6$ \\
\hline & &
\end{tabular}

El fotógrafo con más cantidad de obra en los álbumes de Valderrama es Francisco García Cortés (Velilla de Medinaceli, Soria 1901-Málaga, 1976), profesional de larga trayectoria que comenzó su actividad como ambulante en Tetuán, donde abrió un laboratorio que mantuvo activo hasta la independencia de Marruecos. En los últimos años del Protectorado fue corresponsal de la agencia Efe y fotógrafo oficial de la Alta Comisaría de España en Marruecos, máximo órgano de la Administración, para la que realizó los reportajes de los actos oficiales. Después se trasladó a Ceuta y posteriormente a Málaga, donde abrió dos estudios cuyo negocio continuaron sus hijos. Fue redactor gráfico del Diario de África de Tetuán en 1956, registrado en la Dirección General de Prensa con el número 113. 
Figura 17. Documento del redactor gráfico García Cortés, año 1956. Colección familia García Cortés

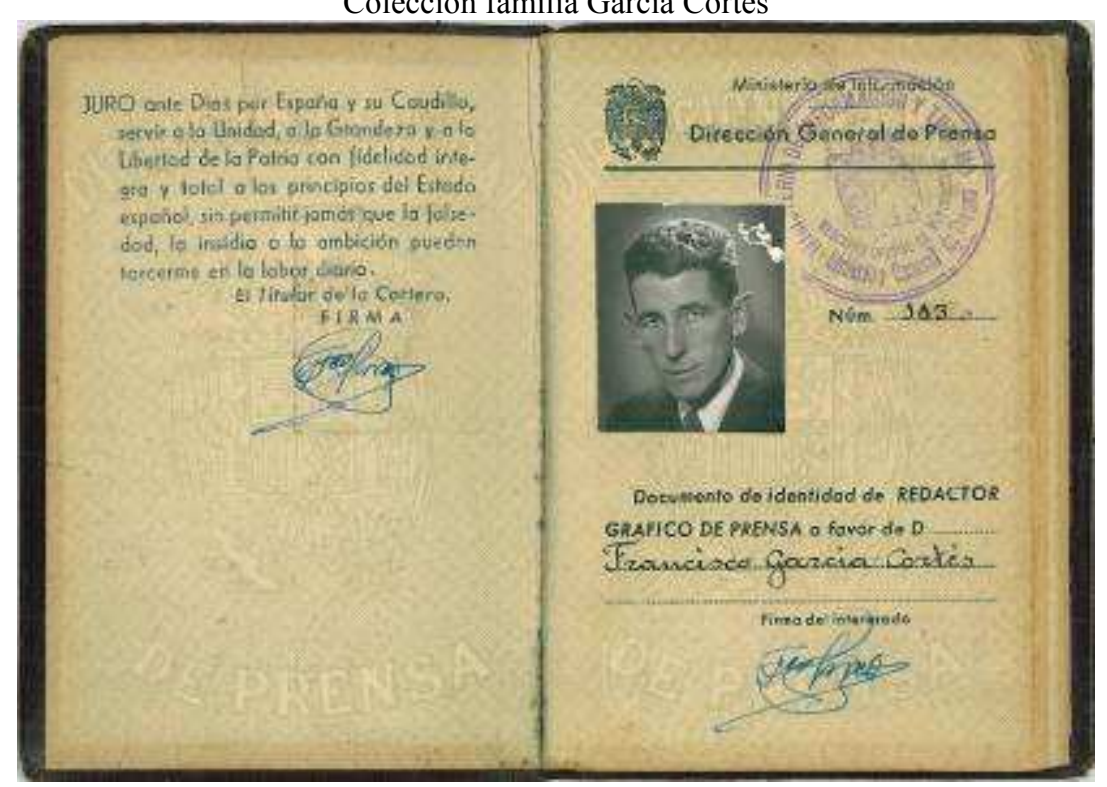

Además de Francisco García Cortés (Figura 17) destacan, por la cantidad de originales, Ulzurrun, Morales, Bartolomé Ros y Vicente Zubillaga, mientras que el resto aparecen esporádicamente. En cuanto a la calidad de las fotografías, a pesar de tratarse de imágenes cuya función es claramente documental, se advierte en ocasiones un componente creativo que va más allá de lo circunstancial, como en el caso de las composiciones de Palacios.

Otro autor con numerosos originales es Merino (Tetuán) si bien sus fotografías responden a un solo reportaje sobre inscripciones, todas ellas en el Álbum 10. De algunos fotógrafos hay pocas imágenes, aunque tuvieron estudios de prestigio en ese territorio español, como es el caso de Alberto (Tetuán), Calatayud (Ceuta), Diodoro (Larache) o Ricart (Alcazarquivir).

\section{CONCLUSIONES}

Los documentos del legado Valderrama son base para el estudio de la actividad cultural en el Protectorado español en Marruecos. La función de la Biblioteca Islámica está siendo clave en la tarea de analizar y difundir los contenidos, y en el desarrollo de dicha tarea se enmarca el trabajo que presentamos.

Este proyecto ha supuesto una oportunidad estratégica para incrementar el conocimiento y uso de la colección. Desde el punto de vista técnico la catalogación de este fondo ha sido muy productiva porque ha generado interés de 
diversos usuarios y acciones de gran visibilidad para la biblioteca dentro del nuevo universo digital en el que circula la información de las instituciones patrimoniales.

Los originales fotográficos del legado contribuyen al estudio de la historia de la fotografía española del Protectorado. La cantidad, calidad y diversidad de copias, tanto por el contenido como por el soporte y la presentación, permiten aportar nueva información y/o profundizar en la obra de cada uno de los autores investigados.

Como resultado de la investigación se han recopilado fotografías de 23 autores, entre los que destaca por la cantidad de originales Francisco García Cortés (Tetuán), representado en prácticamente todos los álbumes, así como Ulzurrun, con estudios en las ciudades de Larache y Tánger.

En cuanto al contenido, el fondo fotográfico ofrece una visión global sobre las instituciones culturales y el desarrollo de las actividades en las mismas, constituyendo la memoria gráfica base de las investigaciones sobre la materia. De gran interés son las tarjetas postales editadas por Hauser y Menet sobre la guerra del Rif, y las imágenes de tipos, tradiciones y costumbres. Se constata así mismo el uso de la fotografía para la investigación, representada por la gran cantidad de documentos gráficos sobre inscripciones árabes, y por otros temas de marcado carácter documental.

La difusión de esta colección asociada al proyecto trasnversal de la biblioteca sobre el Protectorado durante 2012-2013 ha tenido como consecuencia su uso y estudio (este artículo), la solicitud de documentos por la BVA para ser expuestos y la solicitud de Iberdrola (2013) para incluir veinte fotografías en la publicación que se ha comentado.

\section{REFERENCIAS BIBLIOGRÁFICAS}

ALBEROLA FIORAVANTI, María Victoria, Ed. (2004). Homenaje a Fernando Valderrama Martínez. Selección de sus separatas. Madrid: AECID.

ARAGÓN REYES, M. (dir.) (2013) El Protectorado español en Marruecos: la historia trascendida. Bilbao: Iberdrola, D.L. 2013

CARRASCO GARCÍA, Antonio (2011). Las imágenes del desembarco Alhucemas 1925. Madrid: Almena Ediciones

CORTÉS GARCÍA, Manuela (2012). "La personalidad de Fernando Valderrama y la donación de su biblioteca privada", en Cuadernos de la Biblioteca Islámica, $\mathrm{n}^{\circ}$ 181. Madrid: Ministerio de Asuntos Exteriores y Cooperación. AECID, pp. 9-10. Cuadernos de la Biblioteca Islámica (2012). "Donativo de Fernando Valderrama", $\mathrm{n}^{\mathrm{o}}$ 181. Madrid: Agencia Española de Cooperación Internacional para el Desarrollo, pp. 9-10. (2012).

GARCÍA FIGUERAS, Tomás (1957). España y su protectorado en Marruecos (1912-1956). Madrid: Consejo de Investigaciones Científicas.

GIMÉNEZ CABALLERO, Ernesto (1983). Notas Marruecas de un soldado. Madrid: Planeta. 
GÓMEZ BARCELÓ, José Luis. "Documentos gráficos sobre el Protectorado en la Biblioteca Félix María Pareja", en MORA VILLAREJO, Luisa, Editora (2012). El Protectorado español en Marruecos a los 100 años de la firma del Tratado: fondos documentales en la Biblioteca Islámica Félix María Pareja. Madrid: Agencia Española de Cooperación Internacional para el Desarrollo, pp. 23-26.

GÓMEZ BARCELÓ, José Luis (2005). Tiempo de guerra, imágenes de paz. Iconografia militar de Bartolomé Ros. Madrid: Ministerio de Defensa.

GÓMEZ BARCELÓ, José Luis (2007). "Fotografía española en Marruecos: realidades soñadas, ensoñaciones recreadas", en Mélanges de la Casa de Velásquez, $\mathrm{n}^{\circ} 37-1,2007$, pp. 57-81.

GÓMEZ BARCELÓ, José Luis (2013). "El protectorado español en Marruecos: la historia trascendida". Disponible en http://www.lahistoriatrascendida.es/ [2014-02-04].

ICA (2000). ISAD (G): General International Standard Archival Description. Ottawa: ICA.

LÓPEZ ENAMORADO, María Dolores (1989). "Historia gráfica del Protectorado de España en Marruecos: la sección fotográfica de la Biblioteca General y Archivos de Tetuán”. Encuentro Internacional España y el Magreb: ¿confrontación o entendimiento? Ojén (Málaga), 21-24, mayo de 1989.

MARTÍN CORRALES, Eloy (2002). La imagen del magrebi en España. Barcelona: Ediciones Bellaterra.

MORA VILLAREJO, Luisa, editora (2011). El Protectorado español en Marruecos a los 100 años de la firma del Tratado: fondos documentales en la Biblioteca Islámica Félix María Pareja. Madrid: Agencia Española de Cooperación Internacional para el Desarrollo.

MORA VILLAREJO, Luisa; VIZCAÍNO, Juan Manuel (2012). "Difusión de los fondos documentales de la biblioteca islámica en relación con el protectorado en el Norte de África", en Awraq, 5-6, 177-193.

MORA VILLAREJO, Luisa [et al.] (2013). "Biblioteca Islámica "Félix Ma Pareja (AECID-MAEC)", en Clip Boletín de Sedic, $\mathrm{n}^{\circ}$ 67, enero-junio. Disponible en http://www.sedic.es/p_boletinclip67_centrosenmarcha.asp [2014-02-23]

MORA VILLAREJO, Luisa (2014). "Fondos documentales de la Biblioteca Islámica (AECID): difusión del legado fotográfico de Fernando Valderrama", en Encuentro Transfronterizo Memorias Compartidas sobre fondos y colecciones fotográficas en el marco del Proyecto RIMAR. Sevilla: Instituto del patrimonio Histórico Andaluz, pp. 174-187

MULLER, Nicolás (1944). Tánger por el Jalifa. Madrid: Instituto de Estudios Políticos.

MULLER, Nicolás, GIL BENUMEYA, Rodolfo (1944). Estampas marroquies. Madrid: Instituto de Estudios Políticos.

OTEYZA, Luis de (1924). Abd el -Krim y los prisioneros. Madrid: Mundo Latino. 
PENNELL, C. R. (1986) "Éxito y fracaso de Abd el-Krim", en Historia 16, nº126, octubre, pp. 28-36.

RODRÍGUEZ JOULIÁ SAINT-CYR, Carlos (1950). "El archivo fotográfico del Protectorado de España en Marruecos", en Revista de Archivos, Bibliotecas y Museos, 56, pp. 385-388.

SÁNCHEZ VIGIL, Juan Miguel (2014). La fotografia en España. Otra vuelta de tuerca. Gijón: Trea.

SÁNCHEZ VIGIL, Juan Miguel (2007). Del daguerrotipo a la Instamatic. Gijón: Trea.

SÁNCHEZ VIGIL, Juan Miguel (2001). Alfonso: imágenes de un siglo. Madrid: Espasa Calpe.

SÁNCHEZ VIGIL, Juan Miguel (2001). La fotografía en España, de los orígenes al siglo XXI. Madrid: Espasa Calpe.

SÁNCHEZ VIGIL, Juan Miguel (2000). A través del espejo: cómicos, trágicos y mitos. Fotografías de Calvache. Madrid: Espasa Calpe.

SÁNCHEZ VIGIL, Juan Miguel; MARCOS RECIO, Juan Carlos; TOVAR, Ricardo (2007). "Los recursos fotográficos en los periódicos digitales: valores de la fotografía digital" en IBERSID, pp. 211-218.

SÁNCHEZ VIGIL, Juan Miguel; OLIVERA ZALDUA, María (2014). Fotoperiodismo y República. Madrid: Cátedra.

TORRES SANTO DOMINGO, Nuria (1995). "La biblioteca islámica", en I Jornadas de Bibliotecas y centros de documentación sobre el Mundo Árabe e Islám, pp.129-134.

VALDERRAMA MARTÍNEZ, Fernando (1956). Historia de la acción cultural de España en Marruecos, 1912-1956. Tetuán: Editora Marroquí.

VIZCAÍNO, Juan Manuel; ALBEROLA FIORAVANTI, María Victoria (2012). "Donativo de Fernando Valderrama", en Cuadernos de la Biblioteca Islámica, 181. Madrid: Ministerio de Asuntos Exteriores y Cooperación. AECID, pp. 5-6.

Yebala y el bajo Lucus. (1914). Expedición abril-julio 1913. Madrid: Real Sociedad de Historia Natural.

ZUBILLAGA, Vicente (1951). Tánger, proyecto e ilustraciones de V. Zubillaga. Madrid: Artes fotográficas Martorell. 